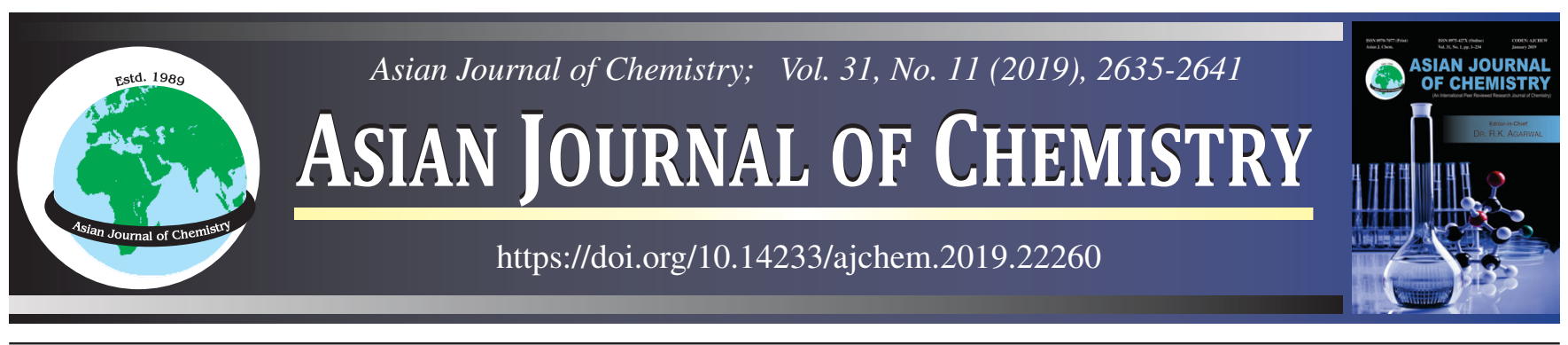

\title{
Entrapment of Glucose Oxidase in Reverse Micelle Microemulsion Systems for Glucose Detection in Lipid Based Food Products
}

\author{
Lovnish Siyal ${ }^{1}$, Benu Kumar ${ }^{1}$, Arpita Bhattacharya ${ }^{2}$ and Rachana Sahney ${ }^{1, *}$
}

${ }^{1}$ Amity Institute of Biotechnology, Amity University Uttar Pradesh, Noida-201313, India

${ }^{2}$ Amity Institute of Nanotechnology, Amity University Uttar Pradesh, Noida-201313, India

*Corresponding author: Fax: +91 120 2431878; Tel.: +91 1202432780 (thru 85); E-mail: rachanasahney@ gmail.com, rsahney@amity.edu

| Entrapment of glucose oxidase $\left(\mathrm{GO}_{\mathrm{x}}\right)$ enzyme in a new reverse micelle emulsion system was studied. The microemulsion consists of aqueous phase (buffered enzyme)/SPAN 85/n-decane. Critical micelle concentration (CMC) of surfactant-SPAN 85 in $n$-decane was determined using dynamic light scattering study and it was used to develop microemulsion system. Most stable and optically transparent microemulsion with entrapped glucose oxidase showed higher values of specific enzyme activity, maximum reaction rate $\left(\mathrm{V}_{\max }\right)$ and turn over number and low value of Michaelis-constant $\left(\mathrm{K}_{\mathrm{m}}\right)$ in comparison to homogeneous $\mathrm{GO}_{\mathrm{x}}$ (enzyme-glucose oxidase) system. The microemulsion system was successfully used to quantify D-glucose in lipid based food products without any sample preparation. Comparison of these results with chemical method (phenol-sulfuric acid method) and commercial kit method used in food industry validate the efficiency of the new proposed system. The study provides new information about the glucose content of some commonly consumed milk based products where nutritional labels do not accurately show true glucose content. These findings provide support for comprehensive glucose labeling to food products commonly used by the children.

Keywords: Enzyme kinetics, Food, Microemulsion, Reverse micelle.

ᄂ - - - - - - - - - - - - - - - - - - - - - - - - - - - -

\section{INTRODUCTION}

Food has straight impact on our health. Nowadays, manufacturers of all packed foods and beverages declare their nutritional content and calorific value, where carbohydrate content is of great significance due to increasing problem of diabetes in the world [1]. The tremendous increase in incident of diabetes coincides with the radical changes of food habits. The continuing interest in opportunities for the personalized prevention and management of diabetes require information of nutritional content in the food. US Food and Drug Administration (FDA) has updated the nutrition facts label requirements where all nutritional labels on food packages will have to provide information on the amount of added sugar by 2019 [2]. Similarly, in India Food Safety and Standard Authority of India (FSSAI) has guidelines for nutritional labels used in food market [3]. In packaged foods and beverages, nutritional information about carbohydrate contents is denoted as total carbohydrate and/or carbohydrate and sugars. The amount and composition of sugars play a decisive role in the sensory properties and acceptability of beverages specifically $[4,5]$. Regular beverages are sweetened with cane or beet sugar, high fructose corn syrup or blends of these sweeteners. These sugars result in a mixture of sucrose and/or fructose and glucose in the final product which has direct impact on the blood glucose profile of the consumer. There are many kind of food products that are formulated with different recipes but the package display different ingredients. Thus, it is essential to analyze the ingredient of food samples, especially glucose for monitoring the quality of product, determine the contaminants or verify the authenticity of products and its use.

Conventional methods for quality control and food safety involve analytical techniques that are expensive and require specific equipment and trained people. Official methods for measuring glucose in different non-aqueous or lipid based products like milk powder, milk based drinks, vegetable oils etc. include chemical, volumetric and polarimetric methods, and gas and anion exchange chromatographic methods [6,7] which involve tedious sample preparation step.

Natural enzymes-glucose oxidase $\left(\mathrm{GO}_{\mathrm{x}}\right)$ as biological catalysts possess remarkable advantages such as high substrate

This is an open access journal, and articles are distributed under the terms of the Attribution 4.0 International (CC BY 4.0) License. This license lets others distribute, remix, tweak, and build upon your work, even commercially, as long as they credit the author for the original creation. You must give appropriate credit, provide a link to the license, and indicate if changes were made. 
specificities and high efficiency under mild conditions. It is used to measure blood glucose level with the system glucose oxidase $\left(\mathrm{GO}_{\mathrm{x}}\right) /$ peroxidase $\left(\mathrm{PO}_{\mathrm{x}}\right) / o$-dianisidine. But this simple enzymatic approach is seldom applied to quasi water free or non-aqueous system or lipid containing food products owing to the complex nature of the food samples containing various water insoluble components which may interfere with the glucose measurement. Thus, sample preparation is a pre-requisite for testing glucose in food samples. For this reason, developing a universal detection and quantification method for glucose in quasi water free or non-aqueous system or lipid based systems has great significance in food analysis [8].

$\mathrm{GO}_{\mathrm{x}}$ is a hydrophilic enzyme. Thus, immobilization is often the key to optimizing the operational performance of an enzyme, especially for use in non-conventional media. One of the easiest and effective methods for regulating enzyme activity in nonconventional media is the enzyme entrapment within water-inoil (W/O) microemulsions. Enzyme activity of $\mathrm{GO}_{\mathrm{x}}$ has been reported in various reverse micellar system $[9,10]$. W/O microemulsions, comprising of water, oil and surfactant forming a single optically isotropic, low-viscosity and thermodynamically stable solution, have been used as an attractive approach for enzyme immobilization to facilitate enzymatic catalysis in nonconventional media, because of their long-term stabilities [11-13]. In these systems, the water phase is dispersed in the organic solvent as tiny droplets surrounded by a monolayer of surfactant molecules, forming the so-called reverse micelles [14]. The study of proteins entrapped in such micro-heterogeneous environments has attracted increasing interest due to their use as model systems for studying enzymatic reactions and their potential application in biotechnology [15-17].

The aim of present study is to entrap glucose oxidase from A. niger in aqueous droplets of W/O microemulsion containing hydrophobic, biodegradable, food grade surfactant SPAN 85 which can be used in non-conventional medium for glucose analysis (free sugar) present in lipid containing food products. In food industry $\mathrm{GO}_{\mathrm{x}}$ is used to remove glucose from dried egg [18] and oxygen from fruit juices and canned beverages [19]. But it is seldom used to measure glucose (free sugar) present in milk based emulsified products like milk powder, milk based drinks, vegetable oils, etc., which has great impact on our health. We selected SPAN 85 surfactant having low value of hydrophile-lipophile balance (HLB) and large molecular mass which has a high partition coefficient to organic phase like $n$-decane and stabilizes reverse micelle in organic phase. This gives rise to new possibilities for the universal use of the method in emulsified systems with no sample preparation step.

\section{EXPERIMENTAL}

Sorbitan trioleate (SPAN 85), (m.w. $957.49 \mathrm{~g} / \mathrm{mol}, \mathrm{HLB}=$ $1.8 \pm 1.1)$, glucose oxidase $\left(\mathrm{GO}_{\mathrm{x}}\right),(\mathrm{EC} 1.1 .3 .4,250 \mathrm{U} / \mathrm{mg}$, from A. niger) were purchased from Sisco Research Laboratories Pvt. Ltd. (SRL), India and $n$-decane was bought from Spectrochem, India. Phosphate buffer and acetate buffers were procured from Merck specialties Pvt. Ltd. All other chemicals were purchased from Fisher Scientific, India. All the chemicals were used as received without any further purification. All experiments were performed using double distilled water. For spectroscopic studies UV-visible spectrophotometer of Ocean Optics DHmini was used. Hydrodynamic diameter was determined using dynamic light scattering (DLS) technique of Malvern instruments (Zetasizer Nano S90) equipped with He-Ne laser of $4 \mathrm{~mW}$ adjusted at $633 \mathrm{~nm}$ of wavelength. Detector receives light scattered at an angle of $90^{\circ}$.

Characterization of reverse micelle and W/O emulsion using dynamic light scattering (DLS) technique: The reverse micellar system composed of $n$-decane and SPAN 85, was prepared by adding different concentration of SPAN 85 ranging from $1-15 \%(\mathrm{w} / \mathrm{w})$ in $1 \mathrm{~mL}$ of organic phase and allowed to stir at $500 \mathrm{rpm}$ for $8 \mathrm{~h}$ with uniform mixing. Hydrodynamic diameters of reverse micelles so obtained was measured at $25 \pm$ $5^{\circ} \mathrm{C}$ using DLS method.

Aqueous phase consisting of $\mathrm{GO}_{\mathrm{x}}$, horse radish peroxidase (HRP) and $o$-dianisidine in phosphate-acetate buffer $(100 \mathrm{mM}$, $7.0 \mathrm{pH}$ ) was added to a vial containing reverse micelle (n-decane and SPAN 85) under constant stirring at $500 \mathrm{rpm}$. Various phases appear (transparent to opaque) during the addition of different volume fractions of aqueous phase. For each distinct phase, $1 \mathrm{~mL}$ aliquot of sample was placed in a quartz cuvette and analyzed using DLS to estimate the mean hydrodynamic size and the polydispersity index (PDI) of emulsion droplets.

Stability of optically transparent W/O microemulsions was checked by measuring the hydrodynamic diameters of aqueous phase droplet for four weeks.

Enzyme assay and steady-state kinetics: The most stable and optically transparent microemulsion (aqueous phase containing $\mathrm{GO}_{\mathrm{x}}, \mathrm{HRP}$ and $o$-dianisidine in buffer/SPAN- $85 / n$-decane) was used for the measurement of enzyme activity. The final concentration of the substrates are: $100 \mu \mathrm{g} o$-dianisidine, $10 \mu \mathrm{g} \mathrm{GO}$ and $5 \mu \mathrm{g}$ HRP referring to $1 \mathrm{~mL}$ micellar solution, respectively. The reaction kinetics was studied using, $5 \mu \mathrm{L}$ substrate solution (glucose of appropriate mass, dissolved in microemulsion containing $0.1 \mathrm{M}$ phosphate-acetate buffer, $\mathrm{pH}$ 7). Enzyme activity of homogeneous $\mathrm{GO}_{\mathrm{x}}$ solution in aqueous buffer system and entrapped $\mathrm{GO}_{\mathrm{x}}$ in microemulsion containing aqueous buffer/SPAN $85 / n$-decane were determined separately on the basis of oxidation of $o$-dianisidine by glucose oxidase/peroxidase coupled system as reported [20,21]. Absorbance was measured at $460 \mathrm{~nm}$ as a function of time for determining reaction rate. Enzyme assay was performed at different glucose concentration varying from 18 to $1800 \mu \mathrm{g} / \mathrm{mL}$ at $25 \pm 5^{\circ} \mathrm{C}$ and $\mathrm{pH} 7.0$ to determine parameters like $\mathrm{V}_{\max }, \mathrm{K}_{\mathrm{m}}$ and turnover number $\left(\mathrm{K}_{\text {cat }}\right)$.

Effect of aqueous phase buffer $\mathrm{pH}$ was studied by measuring enzyme activity at different $\mathrm{pH}$ values of aqueous phase phosphate-acetate buffer solution measured by combined glass $\mathrm{pH}$ electrode at $25 \pm 5^{\circ} \mathrm{C}$. Similarly, enzyme stability in microemulsion system was checked by measuring enzyme activity of $\mathrm{GO}_{\mathrm{x}}$ at different time interval for four weeks and compared it with the homogeneous aqueous $\mathrm{GO}_{\mathrm{x}}$ solution. All the solutions were stored in refrigerator at $4{ }^{\circ} \mathrm{C}$ and brought to $25 \pm 5^{\circ} \mathrm{C}$ before measurement of enzyme activity. Percent residual activity was calculated and plotted against number of days.

The percent immobilization for entrapped $\mathrm{GO}_{\mathrm{x}}$ was calculated as follows:

Immobilization $(\%)=\frac{\text { Specific activity of etrapped } \mathrm{GO}_{\mathrm{x}}}{\text { Specific activity of soluble } \mathrm{GO}_{\mathrm{x}}} \times 100$ 
The residual activity (\%) is calculated for soluble $\mathrm{GO}_{\mathrm{x}}$ and entrapped $\mathrm{GO}_{\mathrm{x}}$ as follows:

$$
\text { Residual activity }(\%)=\frac{\text { Observed activity }\left(\mathrm{GO}_{\mathrm{x}}\right)}{\text { Initial activity }\left(\mathrm{GO}_{\mathrm{x}}\right)} \times 100
$$

Estimation of glucose in food by chemical method: Phenolsulphuric acid method is the standard chemical method for determining total carbohydrate in different food samples. Here, it is used to determine D-glucose in food samples. [22]. In short, $2 \mathrm{~mL}$ of D-glucose solution of appropriate concentration is pipetted into a test tube and $0.05 \mathrm{~mL}$ of $80 \%$ phenol is added to it. Then $5 \mathrm{~mL}$ of concentrated sulfuric acid is added rapidly, directly on the surface of solution to get proper mixing. The tubes were vortexed twice at an interval of $20 \mathrm{~min}$ and then placed in a water bath at $25-30^{\circ} \mathrm{C}$. The absorbance was measured at $490 \mathrm{~nm}$ wavelength. Blank solution was prepared for reference by substituting glucose solution with distilled water. A calibration graph is obtained by plotting absorbance recorded at different glucose concentration.

Estimation of glucose in food by commercial kit method: Commercial-kit method from Megazyme-2018 was used to measure glucose as per manufacturer's instruction. Calibration curve was obtained with D-glucose as standard. It is used to estimate glucose in food samples. Blank solution is prepared for reference by substituting glucose solution with distilled water.

Estimation of glucose in food by proposed method: A calibration graph was obtained at fixed enzyme concentration by plotting absorbance recorded at different glucose concentration. Appropriate emulsion was taken as blank reference. It is used to estimate glucose in food samples. For coloured food samples, blank solution was prepared for reference by substituting coloured solution with distilled water or microemulsion as needed. Sugars are sensitive to heat and acid hydrolysis of polymers under mild conditions. Thus heat and acid conditions are prevented which may cause changes in the monosaccharide content of sugars. Thus, neutral buffer is used in present experiment.

\section{RESULTS AND DISCUSSION}

Encapsulation of $\mathbf{G O}_{x}$ in microemulsion: There is enriched literature available on microemulsion based enzyme immobilization in non-conventional media [23,24], which depicts the hydrophilic reversed micellar inner core as micro-water pool apt for entrapment of hydrophilic enzyme/proteins used in various biotechnological applications. Usually, ionic micellar systems are used for extraction of enzyme, wherein the electrostatic attraction between the inner micellar charge wall and the biomolecules is the main driving force for the transfer of biomolecules from a bulk aqueous phase to polar core of reversed micelles $[9,25,26]$. However, the recovery yield and the separation factor of an ionic reversed micellar extraction are usually low because of the intensive electrostatic interactions and the low selectivity of electrostatic interactions [27]. Furthermore, the intensive electrostatic interactions often lead to enzyme inactivation or protein denaturation resulting from protein unfolding [28-30]. Therefore, for enzyme catalysis applications we chose foodgrade non-ionic surfactant (SPAN 85) for the entrapment of $\mathrm{GO}_{\mathrm{x}}$ with $\mathrm{HLB}$ value less than 7 which promotes W/O emulsions [31]. Here non-ionic surfactant shows less pronounced inter- actions with the enzyme molecules entrapped in the non-ionic hydrophilic core of reverse micelle with minimal effect on its structure, activity/property. We have chosen $n$-decane as the oil phase because of its low dielectric constant $(\varepsilon \sim 1.991)$ and non-volatile nature at room temperature which prevents material loss over the course of our experiments.

It is also desirable to form stable emulsions/microemulsions with a minimum amount of surfactant. The critical micelle concentration (CMC) of surfactants for aqueous-surfactant systems has been well-studied, but few data are available for organic-surfactant systems. Hence, we employed DLS measurements to study the reverse micelle in the organic phase, which allows measurement of hydrodynamic size and provides information on the surfactant's CMC as reported [32-34]. SPAN 85 molecules have highly branched structure which forms relatively larger microstructure in $n$-decane as reverse micelles. The DLS measurement results obtained for SPAN-85 in $n$ decane are shown in Fig. 1. Each data point is averaged from three independent measurements and the standard deviation is calculated. The hydrodynamic diameter of SPAN-85 aggregates in $n$-decane initially showed no gradation up to $22.5 \mathrm{mM}$ of surfactant concentration and PDI value (0.3-0.8), then reveres micelle size increases and attains a roughly constant value of $252 \pm 4.75 \mathrm{~nm}$ over a wide range of concentration. It confirms that SPAN 85 forms stable micellar-type aggregates at concentrations of $62.5 \mathrm{mM}$ or above.

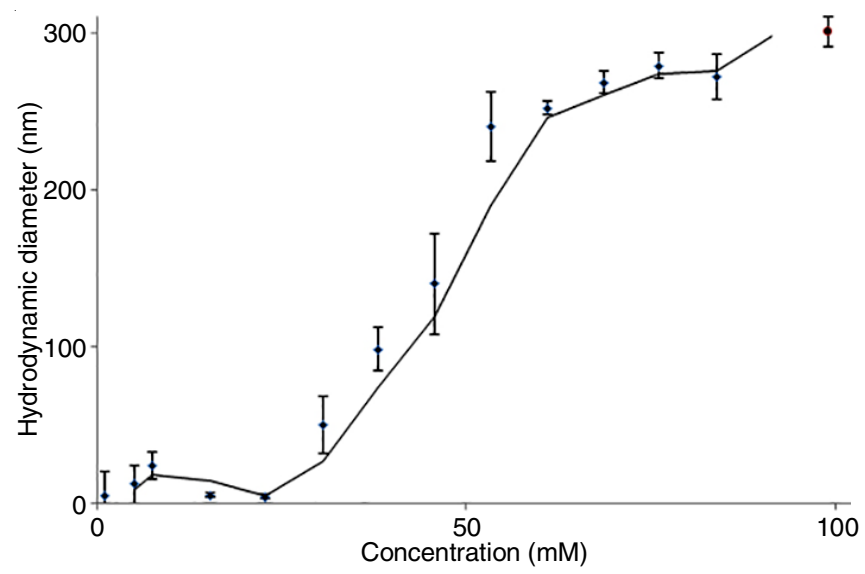

Fig. 1. Apparent hydrodynamic diameter of SPAN 85 aggregates in $n$-decane measured with DLS

Water is fundamental for enzyme activity. In W/O-type emulsions at the $\mathrm{CMC}$ and above, the spherical micelles enclose the aqueous phase in so-called water pools [33,35], where the size of the pool depends on the relative quantity of the aqueous phase as well as the number of surfactant molecules forming the micelles. From practical point of view, glucose assay requires $\mathrm{GO}_{\mathrm{x}}$ along with $\mathrm{HRP}$, glucose and $o$-dianisidine dye for spectrophotometric measurement which are water soluble. Thus, in present system, aqueous phase consists of $\mathrm{GO}_{x}, \mathrm{HRP}$ and $o$-dianisidine in phosphate-acetate buffer. Reasonably satisfactory aqueous phase/SPAN $85 / n$-decane emulsions over a wide range of aqueous phase volume fractions could be prepared. Since buffer solution with enzymes is insoluble in oil (n-decane), the $\mathrm{GO}_{\mathrm{x}}$ is confined within the aqueous boundary. Optically transparent reverse micelle system are produced by dispersion 
of small volume of aqueous phase into oil phase in presence of fixed amount of surfactant known as Winsor IV system [36] and thus enzymes entrapped in a space of low water content in Winsor IV system is suitable for spectroscopic studies. Thus, different amount of aqueous phase was added in reverse micelle containing $62.5 \mathrm{mM}$ SPAN 85 in $1.0 \mathrm{~mL} n$-decane to obtain emulsions and hydrodynamic diameter of swollen reverse micelle was measured by DLS technique. Fig. 2 shows that the size of spherical aqueous droplet grows with the increase of aqueous content. Increasing the degree of hydration of reverse micelle at fixed enzyme concentration leads to the increase in size of inner cavity in reverse micelle system. At constant surfactant: $n$-decane ratio and low aqueous phase concentration region the microemulsion was optically transparent. If the volume of aqueous phase increases beyond $50 \mu \mathrm{L}$, the microemulsion become slightly turbid/translucent to milky appearance as shown in Fig. 3, where bottle A represents Winsor IV system with the droplet size $280.5 \pm 9.2 \mathrm{~nm}$, bottle B represents translucent system with droplet size $424.8 \pm 9.9 \mathrm{~nm}$ and bottle C represents turbid milky system with droplet size $602.7 \pm 6.9 \mathrm{~nm}$, respectively (corresponding DLS data is given in supporting information file). Similar observations are also reported for anionic surfactant (AOT) in isooctane [37]. Molar ratios of water solubilized in a reverse micelle emulsions $\left(\mathrm{W}_{\mathrm{o}}\right)$ are important parameter which has been extensively studied to determine the enzymes hydration rate and its activity. But entrapment of $\mathrm{GO}_{\mathrm{x}} / \mathrm{HRP} / o$-dianisidine in reverse micelle is not exactly immobilization as we observed on solid support. The assemblies are dynamic species and inter-micellar exchange of molecules including proteins is quite fast $[38,39]$ and it causes a rearrangement of reverse micellar aggregates and affect the equilibrium of the system [40]. These systems may show instability like phase separation, sedimentation or creaming due to coalescence and Ostwald's ripening which will affect their application in enzyme catalysis [41]. Thus, we determined the stability at maximum hydration of reverse micelle where W/O microemulsion is optically transparent. Fig. 4 shows the corresponding stability of aqueous droplets in the swollen micelle. The stable microemulsion with aqueous droplet size $280.5 \pm 9.2 \mathrm{~nm}$ do not show any appreciable change in their size are suitable for enzyme kinetics study.

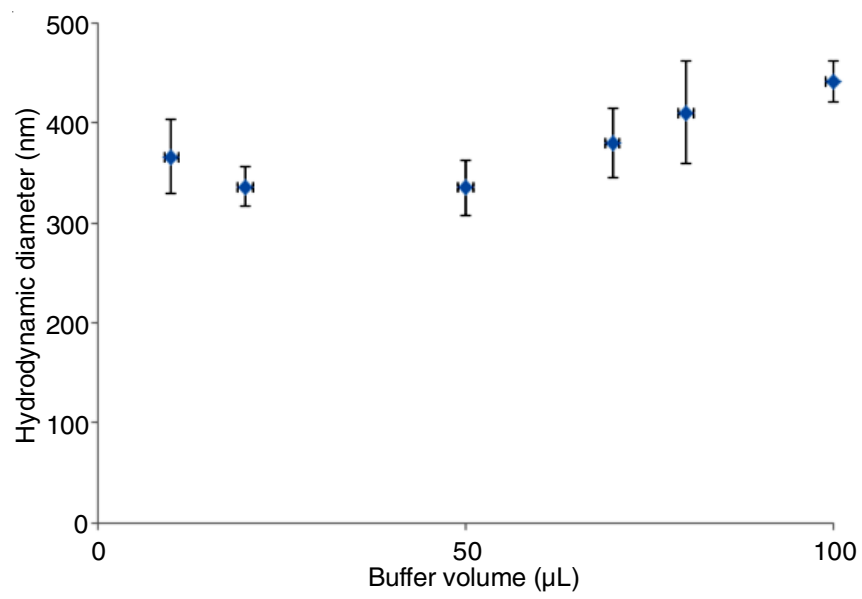

Fig. 2. Variation of $\mathrm{W} / \mathrm{O}$ microemulsion droplet size as a function of aqueous phase volume containing constant

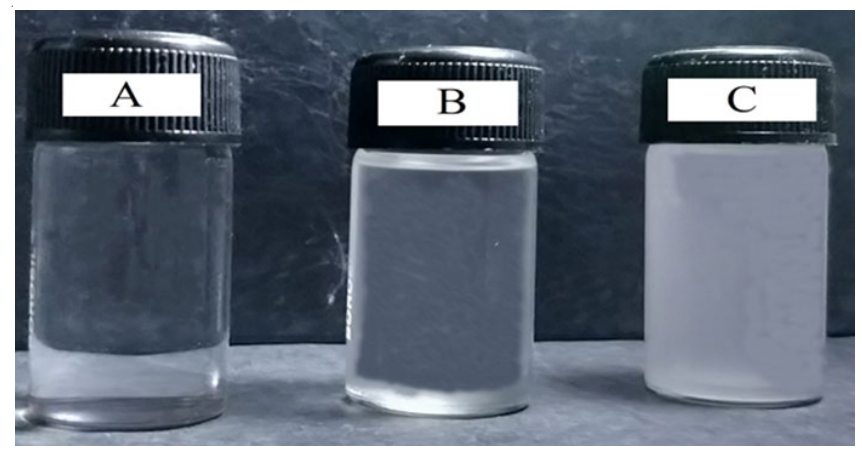

Fig. 3. W/O emulsion representing A: Optically transparent microemulsion; B: slightly turbid emulsion; and C: milky appearance-emulsion obtained by different ratio of Aqueous phase : SPAN $85: n$-decane

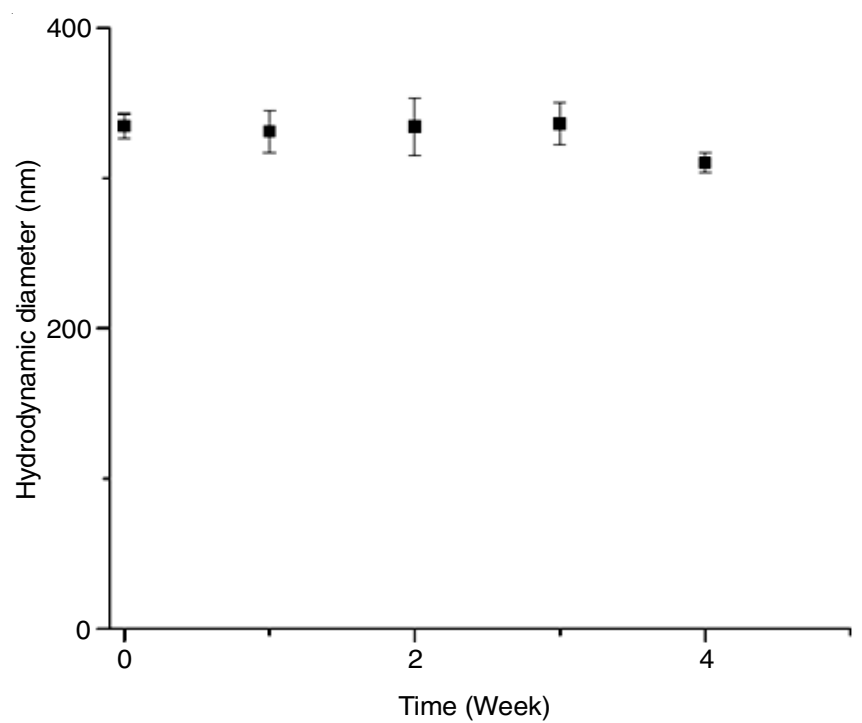

Fig. 4. Stability of aqueous phase droplet containing $\mathrm{GO}_{\mathrm{x}}$ and constant surfactant: $n$-decane ratio as a function of time in week

Enzyme kinetics and glucose determination: Water-inoil is thermodynamically stable single phase dispersions where hyperactivity of HRP and many other enzymes are reported [10,42-45]. In general, the biochemical reaction catalyzed by enzymes in reverse micellar system follows same kinetic behaviour as in homogeneous system. In the present study, kinetic analysis was carried out according to the classical MichaelisMenten equation:

$$
v=\frac{\mathrm{k}_{2}[\mathrm{E}]_{0}[\mathrm{~S}]_{0}}{\mathrm{~K}_{\mathrm{M}}+[\mathrm{S}]_{0}}=\frac{\mathrm{V}_{\text {max }}[\mathrm{S}]_{0}}{\mathrm{~K}_{\mathrm{M}}+[\mathrm{S}]_{0}}
$$

where, $[\mathrm{E}]_{\mathrm{o}}$ and $[\mathrm{S}]_{\mathrm{o}}$ are $\mathrm{GO}_{\mathrm{x}}$ and glucose molar concentrations, respectively, $\mathrm{k}_{2}$ is the first-order catalytic constant, $\mathrm{K}_{\mathrm{M}}$ is the Michaelis constant; and $\mathrm{V}_{\max }=\mathrm{k}_{2}[\mathrm{E}]_{\mathrm{o}}$ is the maximum rate realized at saturation of enzyme with substrate. Keeping overall concentration of $\mathrm{GO}_{\mathrm{x}}, \mathrm{HRP}, o$-dianisidine constant, the analysis of $\mathrm{GO}_{\mathrm{x}}$ reaction kinetics was studied at different glucose concentration in W/O microemulsion system in comparison with homogeneous aqueous solution. It allows the determination of maximum reaction rate $\left(\mathrm{V}_{\max }\right)$, inverse measure of the enzyme's affinity for the substrate $\left(\mathrm{K}_{\mathrm{M}}\right)$, turn-over number $\left(\mathrm{K}_{\text {cat }}\right)$ and catalytic efficiency of $\mathrm{GO}_{\mathrm{x}}$ in these systems as shown in Table-1. In the present study, $o$-dianisidine oxidation to give colour in microemulsion system was faster than in homogeneous aqueous 
solution at the same over-all glucose and same reagent concentration. The enzyme activity of $\mathrm{GO}_{\mathrm{x}}$ in microemulsion system is almost two-fold higher than in homogeneous aqueous solution (Table-1). It is apparent that $\mathrm{GO}_{\mathrm{x}}$ is comparatively more active in the present non-ionic micellar system. For lyophilized $\mathrm{GO}_{\mathrm{x}}$ in aqueous buffered system $\mathrm{K}_{\mathrm{M}}$ amounts to $8.9 \mathrm{mM}$ while it is smaller $(6.87 \mathrm{mM})$ at maximum aqueous phase concentration in reverse micelle microemulsion system showing better affinity of D-glucose towards $\mathrm{GO}_{\mathrm{x}}$ in the system. Different models are proposed to explain higher activity of enzymes in W/O microemulsions. Practically, transfer of hydrophilic glucose molecule entrapped in a reverse micelle to swollen micelle containing $\mathrm{GO}_{\mathrm{x}}$ controls the rate of reaction.

Homogeneous biochemical reactions are highly sensitive to $\mathrm{pH}$ of the buffer solution used as reaction medium. Strategies to study the effective $\mathrm{pH}$ of water core inside the swollen reverse micelle are not standard. Thus, we determined the $\mathrm{GO}_{\mathrm{x}}$ activity as the function of $\mathrm{pH}$ of aqueous phase buffer solution used in present study to develop microemulsion. The $\mathrm{pH}$ optimum for homogeneous solution of $\mathrm{GO}_{\mathrm{x}}$ is 5.5 but for microemulsion at $25^{\circ} \mathrm{C}$, enzyme activity was almost constant between $\mathrm{pH}$ 5.5-7 as shown in Fig. 5. At present, it is not possible to explain this effect. Mukherjee et al. [46] had reported that a proton gradient exists inside the water-pool of charged reverse micelles. Possibly, in our case the reverse micelle is non-ionic in nature with nonpolarizable groups, thus no proton gradient is present which may affect the enzyme activity. Hence, $\mathrm{pH}$ of buffer forming aqueous phase do not affect the over-all $\mathrm{GO}_{\mathrm{x}}$ reaction.

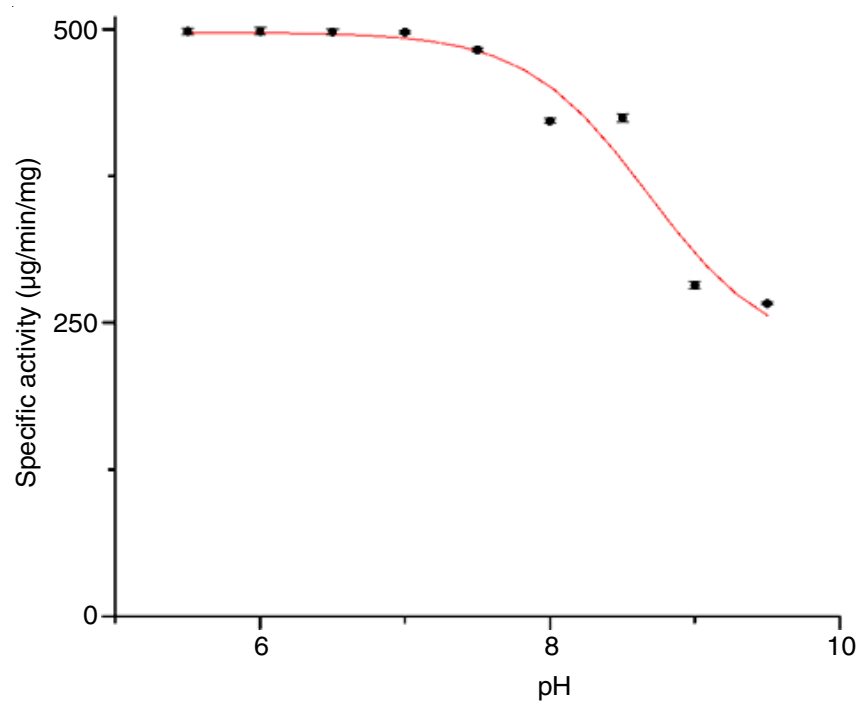

Fig. 5. Dependence of $\mathrm{GO}_{\mathrm{x}}$ enzyme activity on the $\mathrm{pH}$ value of aqueous phase buffer used to develop microemulsion

Storage and stability of $\mathrm{GO}_{\mathrm{x}}$ in microemulsion: The microemulsion containing enzymes, $o$-dianisidine and homogeneous aqueous solution were stored at $4{ }^{\circ} \mathrm{C}$ for 4 weeks and enzyme activity of $\mathrm{GO}_{\mathrm{x}}$ was determined at $25^{\circ} \mathrm{C}$. Residual enzyme activity was calculated. Fig. 6 shows the variation of percent residual $\mathrm{GO}_{x}$ activity in microemulsion system in comparison to the aqueous homogenous system. The enzyme activity is more than $90 \%$ for entrapped $\mathrm{GO}_{\mathrm{x}}$ confirms its suitability for storage in bottles.

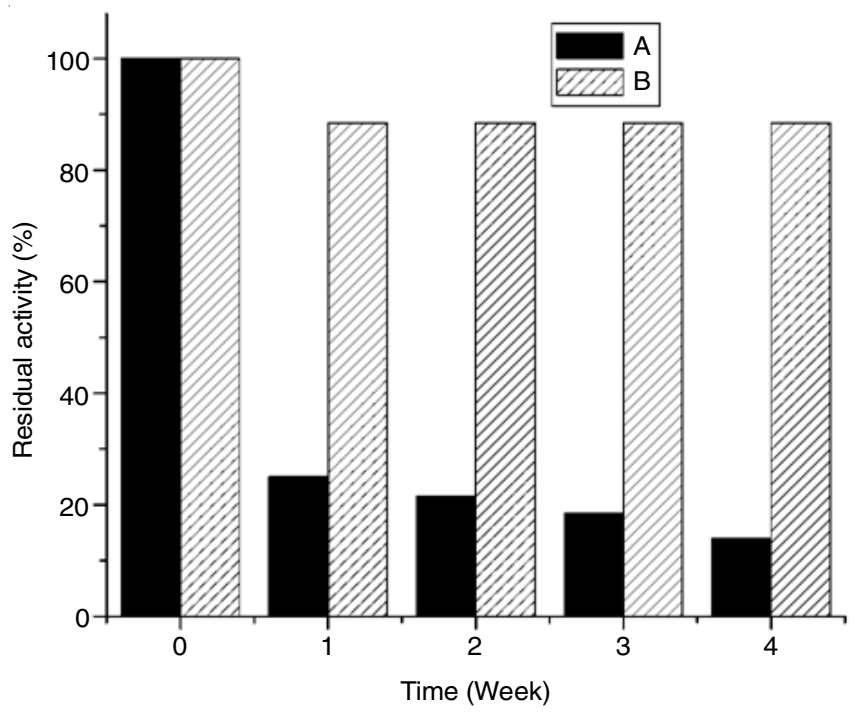

Fig. 6. Stability of $\mathrm{GO}_{\mathrm{x}}$ : (A) in phosphate-acetate buffer and (B) entrapped in W/O microemulsion over a period of 4 weeks

Estimation of glucose in different food products: The microemulsion system containing $\mathrm{GO}_{\mathrm{x}}-\mathrm{HRP}$ enzyme coupled with $o$-dianisidine was applied to the analysis of lipid containing food stuffs like commercial milk based drinks, oil and beer. For most lipid containing foods, sample preparation is an important step where water soluble carbohydrates like D-glucose measurement using commercial enzyme based kit can not be achieved without extraction of lipids and lipid soluble substances. Here, D-glucose content was directly analyzed in five replicates without any specific sample preparation step. The results were compared with the colorimetric method used for total carbohydrate determination [22] and glucose determination by commercial glucose assay kit for its validity. W/O microemulsion consists of aqueous phase dispersed in oil phase where hydrophobic components like lipid molecules or lipid soluble molecules can diffuse in oil phase and hydrophilic components can move to aqueous phase by diffusion. Thus, it is assumed that the lipid molecules from food products were dissolved in the oil phase and do not interfere with the glucose and enzymes present in the aqueous phase. Calibration graph was obtained by using D-glucose as standard for present W/O microemulsion method as shown in Fig. 7. It has a good linear calibration range which can detect glucose from 18 to $900 \mu \mathrm{g} /$ $\mathrm{mL}$ of D-glucose sample with a good linear regression coefficient $\left(\mathrm{R}^{2}\right)$ of 0.9926 . Table-2 shows the amount of glucose measured

TABLE-1

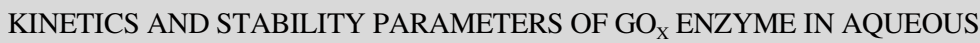
BUFFER SOLUTION AND ENTRAPPED W/O MICROEMULSION

\begin{tabular}{lcccccc}
\hline Enzyme condition & $\begin{array}{c}\text { Specific activity } \\
(\mu \mathrm{mol} / \mathrm{min} / \mathrm{mg})\end{array}$ & $\begin{array}{c}\text { Immobilization } \\
(\%)\end{array}$ & $\begin{array}{c}\mathrm{V}_{\max } \\
(\mathrm{mM} / \mathrm{min})\end{array}$ & $\begin{array}{c}\mathrm{K}_{\mathrm{m}} \\
(\mathrm{mM})\end{array}$ & $\begin{array}{c}\text { Turn over } \\
\text { No. }\left(\mathrm{s}^{-1}\right)\end{array}$ & $\begin{array}{c}\text { Storage and stability with } \\
90 \% \text { activity }(\mathrm{days})\end{array}$ \\
\hline Aqueous $\mathrm{GO}_{\mathrm{X}}$ & 236.36 & - & 0.78 & 8.9 & $6.2 \times 10^{5}$ & 7 \\
Immobilized $\mathrm{GO}_{\mathrm{X}}$ & 475.75 & 201.28 & 1.57 & 6.87 & $1.3 \times 10^{6}$ & 30 \\
\hline
\end{tabular}




\begin{tabular}{|c|c|c|c|c|c|c|c|}
\hline \multirow[b]{3}{*}{$\begin{array}{l}\text { Sample } \\
\text { name }\end{array}$} & \multicolumn{6}{|c|}{$\begin{array}{l}\text { TABLE-2 } \\
\text { GLUCOSE ASSAY OF DIFFERENT FOOD PRODUCTS WITH DIFFERENT METHOD FOR } \\
\text { THE DETERMINATION OF CARBOHYDRATE AND GLUCOSE CONTENT }\end{array}$} & \\
\hline & & edients & \multirow[b]{2}{*}{ Nature of sample } & \multirow[b]{2}{*}{ Additives } & \multicolumn{3}{|c|}{ Methods } \\
\hline & $\begin{array}{c}\text { Carbohydrate } \\
\text { content }\end{array}$ & Sugar/glucose & & & $\begin{array}{c}\text { A (Total } \\
\text { carbohydrate } \\
\text { as glucose) }\end{array}$ & $\begin{array}{l}\text { B (Only } \\
\text { glucose) }\end{array}$ & $\begin{array}{l}\mathrm{C}(\text { Only } \\
\text { glucose })\end{array}$ \\
\hline Toned milk & $5.1 \mathrm{~g} / 100 \mathrm{~mL}$ & $\$$ & Emulsified mixture & $\$$ & $\begin{array}{l}4.6 \pm 0.25 \\
\mathrm{~g} / 100 \mathrm{~mL}\end{array}$ & $\begin{array}{l}1.3 \pm 0.01 \\
\mathrm{~g} / 100 \mathrm{~mL}\end{array}$ & $\begin{array}{l}1.5 \pm 0.25 \\
\mathrm{~g} / 100 \mathrm{~mL}\end{array}$ \\
\hline Soya milk & $\begin{array}{l}24.6 \mathrm{~g} / 200 \\
\mathrm{~mL}\end{array}$ & $\begin{array}{l}\text { Sugar }=21.0 \mathrm{~g} / 200 \\
\mathrm{~mL} ; \text { Glucose }=\$\end{array}$ & Emulsified mixture & $\begin{array}{l}\text { Contains added } \\
\text { flavour }\end{array}$ & $\begin{array}{l}21.2 \pm 1.17 \\
\mathrm{~g} / 200 \mathrm{~mL}\end{array}$ & $\begin{array}{l}0.7 \pm 0.14 \\
\mathrm{~g} / 100 \mathrm{~mL}\end{array}$ & $\begin{array}{l}0.6 \pm 0.06 \\
\mathrm{~g} / 100 \mathrm{~mL}\end{array}$ \\
\hline $\begin{array}{l}\text { Milk } \\
\text { powder }\end{array}$ & $59.8 \mathrm{~g} / 100 \mathrm{~g}$ & $\begin{array}{l}\text { Sugar }=57.6 \mathrm{~g} / 100 \\
\mathrm{~g} ; \text { Glucose }=\$\end{array}$ & $\begin{array}{l}\text { Nature of sample is } \\
\text { Powder made into } \\
\text { solution as per } \\
\text { manufacturer } \\
\text { instruction }\end{array}$ & $\begin{array}{l}\text { Contains } \\
\text { stabilizer }(339 \\
\text { (iii)) }\end{array}$ & $\begin{array}{l}55.4 \pm 0.29 \\
\mathrm{~g} / 100 \mathrm{~g}\end{array}$ & $\begin{array}{l}2.8 \pm 4.4 \\
\mathrm{~g} / 100 \mathrm{~g}\end{array}$ & $\begin{array}{l}2.6 \pm 0.6 \\
\mathrm{~g} / 100 \mathrm{~g}\end{array}$ \\
\hline Horlicks & $78 \mathrm{~g} / 100 \mathrm{~g}$ & $\begin{array}{l}\text { Sugar }=32 \mathrm{~g} / 100 \\
\mathrm{~g} ; \text { Glucose }=\$\end{array}$ & $\begin{array}{l}\text { Nature of sample is } \\
\text { Powder made into } \\
\text { solution as per } \\
\text { manufacturer } \\
\text { instruction }\end{array}$ & $\begin{array}{l}\text { Contains } \\
\text { permitted natural } \\
\text { colour and added } \\
\text { flavour }\end{array}$ & $\begin{array}{l}63.5 \pm 2.5 \\
\mathrm{~g} / 100 \mathrm{~g}\end{array}$ & $\begin{array}{c}3.4 \pm 0.79 \\
\mathrm{~g} / 100 \mathrm{~g}\end{array}$ & $\begin{array}{l}2.8 \pm 0.2 \\
\mathrm{~g} / 100 \mathrm{~g}\end{array}$ \\
\hline Lager beer & $11 \mathrm{~g} / 100 \mathrm{~mL}$ & $\begin{array}{l}\text { Sugar }=0.0 \mathrm{~g} / 100 \\
\mathrm{~mL} ; \text { Glucose }=\$\end{array}$ & Alcoholic & $\begin{array}{l}\text { No preservative } \\
\text { and flavor added }\end{array}$ & $\begin{array}{l}7.4 \pm 1.9 \\
\mathrm{~g} / 100 \mathrm{~mL}\end{array}$ & $\begin{array}{c}0.05 \pm 0.03 \\
\mathrm{~g} / 100 \mathrm{~mL}\end{array}$ & $\begin{array}{c}0.09 \pm 0.02 \\
\mathrm{~g} / 100 \mathrm{~mL}\end{array}$ \\
\hline $\begin{array}{l}\text { Premium } \\
\text { beer }\end{array}$ & $\begin{array}{l}\text { Not } \\
\text { mentioned }\end{array}$ & $\$$ & Alcoholic & $\$$ & $\begin{array}{l}4.5 \pm 2.7 \\
\mathrm{~g} / 100 \mathrm{~mL}\end{array}$ & $\begin{array}{c}0.04 \pm 0.01 \\
\mathrm{~g} / 100 \mathrm{~mL}\end{array}$ & $\begin{array}{c}0.14 \pm 0.06 \\
\mathrm{~g} / 100 \mathrm{~mL}\end{array}$ \\
\hline Olive oil & $0 \mathrm{~g} / 100 \mathrm{~g}$ & $\begin{array}{l}\text { Sugar }=0 \mathrm{~g} / 100 \mathrm{~g} \\
\text { Glucose }=\$\end{array}$ & Emulsified mixture & $\$$ & $\begin{array}{l}7.4 \pm 2.17 \\
\mathrm{~g} / 100 \mathrm{~g}\end{array}$ & $\begin{array}{l}0.06 \pm 0.02 \\
\mathrm{~g} / 100 \mathrm{~g}\end{array}$ & $\begin{array}{c}0.08 \pm 0.001 \\
\mathrm{~g} / 100 \mathrm{~g}\end{array}$ \\
\hline $\begin{array}{l}\text { Rice bran } \\
\text { oil }\end{array}$ & $0 \mathrm{~g} / 100 \mathrm{~g}$ & $\$$ & Emulsified mixture & $\$$ & $\begin{array}{l}32.7 \pm 0.56 \\
\mathrm{~g} / 100 \mathrm{~g}\end{array}$ & $\begin{array}{c}0.11 \pm 0.02 \\
\mathrm{~g} / 100 \mathrm{~g}\end{array}$ & $\begin{array}{c}0.14 \pm 0.01 \\
\mathrm{~g} / 100 \mathrm{~g}\end{array}$ \\
\hline
\end{tabular}

$* \$=$ Not labeled; $\mathrm{A}=$ Phenol-Sulfuric acid method for total carbohydrate determination, $\mathrm{B}=$ Enzymatic glucose determination by commercial kit and $\mathrm{C}=$ Present method developed in our lab

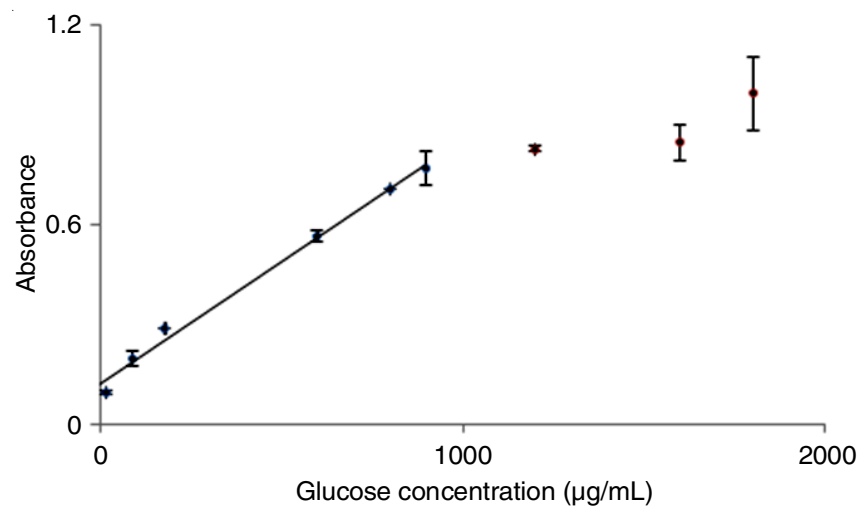

Fig. 7. Calibration plot of glucose determination obtained by present W/O microemulsion method

with chemical method (phenol/sulfuric acid reaction system) [22], glucose measured by commercial kit (Megazyme GOPOD enzyme assay) and present W/O microemulsion method. As can be seen from Table-2, there is a good agreement between the results obtained with W/O microemulsion based method and the reference photometric kit. It is interesting to observe that the results obtained with the reference spectrophotometric kit all show slightly higher values, probably because of the multienzyme cascade reactions, which take place in the kit and that can cause interferences from other compounds, especially other sugars, whereas the microemulsion system based method is strictly specific for glucose as demonstrated above.

\section{Conclusion}

The glucose oxidase activity is studied in a new microemulsion system consist of aqueous phase $\left(\mathrm{GO}_{\mathrm{x}} / \mathrm{HRP} / \mathrm{o}\right.$-dianisidine in phosphate-acetate buffer)/SPAN $85 / n$-decane where
SPAN 85 in $n$-decane forms stable reverse micelle at CMC of $62.5 \mathrm{mM}$ and above with hydrodynamic size of $252 \pm 4.75 \mathrm{~nm}$. Addition of aqueous phase $(5-50 \mu \mathrm{L})$ to the stable reverse micelle system gives swollen micelles which is optically transparent $\mathrm{W} / \mathrm{O}$ microemulsion. At aqueous phase concentration of $50 \mu \mathrm{L}$ and droplet size $280.5 \pm 9.2 \mathrm{~nm}$, W/O microemulsion is stable for 4 weeks. $\mathrm{GO}_{\mathrm{x}}$ enzyme activity measured in microemulsion is double in comparison to homogeneous enzyme solution at $\mathrm{pH} 7$ and it is almost constant between $\mathrm{pH}$ 5.5-7 of aqueous phase buffer dispersed in microemulsion. The $\mathrm{K}_{\mathrm{m}}$ value for $\mathrm{GO}_{\mathrm{x}}$ biochemical reaction is $6.87 \mathrm{mM}$ and turnover number is $1.3 \times 10^{6} \mathrm{~s}^{-1}$ showing high activity of $\mathrm{GO}_{\mathrm{x}}$ in microemulsion, practically useful for D-glucose measurement in food samples. It shows a good linear range of glucose detection which can detect glucose from 18 to $900 \mu \mathrm{g} / \mathrm{mL}$ with a good linear regression coefficient $\left(\mathrm{R}^{2}\right)$ of 0.9926 . It is a new, rapid and easy method for determination of D-glucose in food samples. The preparation of the spectrophotometric kit is very simple, low-cost and quick. It does not require a sample preparation step for liquid samples. The detection method was not influenced by presence of lipid molecules or lipid soluble components in food matrices which can act as possible interferents. This microemulsion system can be developed into enzymatic test-kits with ready to use reagents widely used for the analysis of glucose in food products which will bring huge improvement in the laboratory. The colorimetric method is based on specificity of $\mathrm{GO}_{\mathrm{x}}$ for glucose which is measured in a few samples by a simple photometer in a small laboratory and outstanding reagents can be stored for further usage. In big laboratories with automation, the liquid reagents can be directly used on any biochemistry analyzer. 


\section{ACKNOWLEDGEMENTS}

This work was supported by the DBT, New Delhi, India under a Bio-CARe Women Scientist Scheme award to one of the authors (RS), [Grant No.BT/Bio-CARe/05/640/2011-12].

\section{CONFLICT OF INTEREST}

The authors declare that there is no conflict of interests regarding the publication of this article.

\section{REFERENCES}

1. B.M. Popkin and W.R. Kenan Jr., Best Pract. Res. Clin. Endocrinol. Metab., 30, 373 (2016);

https://doi.org/10.1016/j.beem.2016.05.001.

2. https://www.fda.gov/food/guidanceregulation/guidancedocumentsregulatoryinformation/labeli ngnutrition/ucm 385663.htm.

3. https://foodsafetyhelpline.com/fssai-drafts-new-labelling-and-displayregulations-2018/.

4. V. Andrés, M.D. Tenorio and M.J. Villanueva, Food Chem., 173, 1100 (2015);

https://doi.org/10.1016/j.foodchem.2014.10.136.

5. H. Kelebek, S. Selli, A. Canbas and T. Cabaroglu, Microchem. J., 91, 187 (2009);

https://doi.org/10.1016/j.microc.2008.10.008.

6. J.N. BeMiller, ed.: S.S. Nielsen, Carbohydrate Analysis, In: Food Analysis, Springer International Publishing: Cham. pp. 333-360 (2017).

7. FSSAI, Manual of Methods of Analysis of Foods, In: Lab Manual 4. Government of India. p. 146 (2015).

8. R. Monosik, M. Stredansky, J. Tkac and E. Sturdik, Food Anal. Methods, 5, 40 (2012); https://doi.org/10.1007/s12161-011-9222-4

9. L.F.P. Ferreira, M.E. Taqueda, M. Vitolo, A. Converti and A. Pessoa Jr., J. Biotechnol., 116, 411 (2005);

https://doi.org/10.1016/j.jbiotec.2004.12.005.

10. A. Kamyshny, D. Trofimova, S. Magdassi and A. Levashov, Colloids Surf. B Biointerfaces, 24, 177 (2002); https://doi.org/10.1016/S0927-7765(01)00238-7.

11. N. Garti, Curr. Opin. Colloid Interface Sci., 8, 197 (2003); https://doi.org/10.1016/S1359-0294(03)00022-0.

12. D. Mandal, M. Ghosh, S. Maiti, K. Das and P.K. Das, Colloids Surf. B Biointerfaces, 113, 442 (2014); https://doi.org/10.1016/j.colsurfb.2013.09.047.

13. D.J. McClements, Soft Matter, 7, 2297 (2011); https://doi.org/10.1039/C0SM00549E

14. N.M. Correa, J.J. Silber, R.E. Riter and N.E. Levinger, Chem. Rev., 112, 4569 (2012); https://doi.org/10.1021/cr200254q.

15. S. Ghani, H. Barzegar, M. Noshad and M. Hojjati, Int. J. Biol. Macromol., 112, 197 (2018); https://doi.org/10.1016/j.ijbiomac.2018.01.145.

16. N.L. Klyachko and A.V. Levashov, Curr. Opin. Colloid Interface Sci., 8, 179 (2003); https://doi.org/10.1016/S1359-0294(03)00016-5.

17. K. Tonova and Z. Lazarova, Biotechnol. Adv., 26, 516 (2008); https://doi.org/10.1016/j.biotechadv.2008.06.002.

18. R.R. Baldwin, H.A. Campbell, R. Thiessen Jr. and G.J. Lorant, Food Technol., 7, 275 (1953).

19. W.J. Stadelman and O.J. Cotterill, Enzyme Fermentation, In: Egg Science and Technology, CRC Press, p. 329 (1995).

20. H. Bergmeyer, J. Bergmeyer and M. Grassl, Methods of Enzymatic Analysis; Volume 2: Samples, Reagents, Assessment of Results. 1983: Deerfield Beach, Florida, Verlag Chemie.

21. J. Duley and R.S. Holmes, Anal. Biochem., 69, 164 (1975); https://doi.org/10.1016/0003-2697(75)90577-1.

22. S.S. Nielsen, Phenol-Sulfuric Acid Method for Total Carbohydrates, In: Food Analysis Laboratory Manual, Springer-Verlag: USA, pp. 4753 (2010).
23. A. Braga and I. Belo, eds.: M.A. Coelho and B.D. Ribeiro, Biocatalysis in Micellar Systems, In: White Biotechnology for Sustainable Chemistry, Royal Society of Chemistry, Chap. 7, pp. 178-193 (2015).

24. H. Chen, L.-H. Liu, L.-S. Wang, C.-B. Ching, H.-W. Yu and Y.-Y. Yang, Adv. Funct. Mater., 18, 95 (2008); https://doi.org/10.1002/adfm.200600452.

25. M. Dekker, K.V. Riet, B.H. Bijsterbosch, P. Fijneman and R. Hilhorst, Chem. Eng. Sci., 45, 2949 (1990); https://doi.org/10.1016/0009-2509(90)80186-I.

26. D. Jayachandran, S. Chityala, A.A. Prabhu and V.V. Dasu, Protein Expr. Purif., 157, 1 (2019); https://doi.org/10.1016/j.pep.2019.01.002.

27. M. Pires, M. Aires-Barros and J. Cabral, Biotechnol. Prog., 12, 290 (1996); https://doi.org/10.1021/bp9500501.

28. K. Holmberg, Colloids Surf. B Biointerfaces, 168, 169 (2018); https://doi.org/10.1016/j.colsurfb.2017.12.002.

29. S. Ichikawa, M. Imai and M. Shimizu, Biotechnol. Bioeng., 39, 20 (1992); https://doi.org/10.1002/bit.260390105.

30. E. Melo, C. Carvalho, M. Aires-Barros, S. Costa and J. Cabral, Biotechnol. Bioeng., 58, 380 (1998); https://doi.org/10.1002/(SICI)1097-0290(19980520)58:4<380::AIDBIT5>3.0.CO;2-F

31. T. Tadros, P. Izquierdo, J. Esquena and C. Solans, Adv. Colloid Interface Sci., 108-109, 303 (2004); https://doi.org/10.1016/j.cis.2003.10.023.

32. B.J. Berne and R. Pecora, Dynamic Light Scattering: With Applications to Chemistry, Biology and Physics, Courier Corporation (2000).

33. A. Saxena, A. Bhattacharya, S. Kumar, I.R. Epstein and R. Sahney, J. Colloid Interface Sci., 490, 452 (2017); https://doi.org/10.1016/j.jcis.2016.11.030.

34. M. Zulauf and H.F. Eicke, J. Phys. Chem., 83, 480 (1979); https://doi.org/10.1021/j100467a011.

35. M.A. Sedgwick, D. Crans and N. Levinger, Langmuir, 25, 5496 (2009); https://doi.org/10.1021/la8035067.

36. A. Koneva, E. Safonova, P. Kondrakhina, M. Vovk, A. Lezov, Y.S. Chernyshev and N. Smirnova, Colloids Surf. A Physicochem. Eng. Asp., 518, 273 (2017); https://doi.org/10.1016/j.colsurfa.2017.01.020.

37. J. Su, D. Wang, L. Norbel, J. Shen, Z. Zhao, Y. Dou, T. Peng, J. Shi, S. Mathur, C. Fan and S. Song, Anal. Chem., 89, 2531 (2017); https://doi.org/10.1021/acs.analchem.6b04729.

38. P.L. Luisi, L. Magid and J.H. Fendler, Critical Revs. Biochem., 20, 409 (1986); https://doi.org/10.3109/10409238609081999.

39. L. Thudi, L.S. Jasti, Y. Swarnalatha, N.W. Fadnavis, K. Mulani, S. Deokar and S. Ponrathnam, J. Mol. Catal., B Enzym., 74, 54 (2012); https://doi.org/10.1016/j.molcatb.2011.08.014.

40. E. Mitsou, A. Xenakis and M. Zoumpanioti, Catalysts, 7, 52 (2017); https://doi.org/10.3390/catal7020052.

41. M. Porras, C. Solans, C. González, A. Martínez, A. Guinart and J.M. Gutiérrez, Colloids Surf. A Physicochem. Eng. Asp., 249, 115 (2004); https://doi.org/10.1016/j.colsurfa.2004.08.060.

42. M.A. Biasutti, E.B. Abuin, J.J. Silber, N.M. Correa and E.A. Lissi, Adv. Colloid Interface Sci., 136, 1 (2008); https://doi.org/10.1016/i.cis.2007.07.001.

43. L. Gbicka and J. Pawlak, J. Mol. Catal., B: Enzym., 2, 185 (1997); https://doi.org/10.1016/S1381-1177(96)00022-7.

44. E. Mitsou, E.P. Kalogianni, D. Georgiou, H. Stamatis, A. Xenakis and M. Zoumpanioti, Langmuir, 35, 150 (2019); https://doi.org/10.1021/acs.langmuir.8b03124.

45. C. Oldfield, R.B. Freedman and B.H. Robinson, Faraday Discuss., 129, 247 (2005) https://doi.org/10.1039/B406483F.

46. P. Mukherjee, S. Gupta, S. Rafiq, R. Yadav, V.K. Jain, J. Raval and P. Sen, Langmuir, 32, 1693 (2016); https://doi.org/10.1021/acs.langmuir.5b04429. 